\title{
Ecofeminist Activism and the Greening of Native America
}

\author{
"A nation is not conquered until the hearts of \\ its women are on the ground. Then, it is fin- \\ ished no matter how brave its warriors or how \\ strong their weapons." -Cheyenne Proverb
}

\section{Tina Parke-Sutherland}

Stephens College

\begin{abstract}
Ancient female-centered Native American myths reveal pre-colonial attitudes about gender, gender roles, and sexuality as well as about human persons' essential relations with the non-human world. Girls and women in these stories variously function as creators, embodiments of the sacred, and culture-bringers. After settler colonialism, the subsistence contract embodied in these women-centered myths was broken. On Native lands, unparalleled ecological disaster followed. Since then, Native people and their lands have suffered. Women and girls have doubly suffered from the colonizing culture and its patriarchal institutions as well as from their own cultures' adopted misogyny. But in the last few decades, Native girls and women have taken the lead in rejecting the false choice between prosperity and sustainability. Their ecofeminist activism has spread throughout Native America, perhaps most successfully in the Southwest with the Hopi and Navajo Black Mesa Water Coalition and in North Dakota with the Water Protectors encampment on the Standing Rock Reservation to block the Dakota Access Oil Pipeline. This essay details those two inspirational projects that, in the words of Pueblo poet Simon Ortiz, bear witness to "a spring wind / rising / from Sand Creek."
\end{abstract}

Keywords: Native American, ecofeminist activism, Black Mesa Water Coalition, Water Protectors, Standing Rock Reservation. 
In the "Preface" to the 1988 edition of Custer Died for Your Sins, Vine Deloria, Jr., looks optimistically toward the emergence of a new alliance between young reservation activists and traditional elders:

As these two groups interact and influence each other, powerful spiritual and cultural forces are being unleashed in the tribes, and a vision for the future is being created. In the next generation we shall see some marvelous things coming from the Indian tribes, assuming that the present generation can successfully defend the reservations against the continuing attacks of racists and corporate exploiters. ${ }^{1}$

Deloria's forecast was right, of course - "marvelous things" indeed are happening on many reservations today, largely energized by the combined forces of traditional elders and activist young people. The enemies stay the same too: "racists and corporate exploiters." But Deloria does not foresee, or at least fails to mention, that those activists and elders are largely women. His silence opens up a space that this essay occupies: an analysis of two movements - the Black Mesa Water Coalition and the Standing Rock Water Protectors-led by Indigenous women acting as women as well as tribal people, concerned, like their ecofeminist sisters and grandmothers around the world, with the right and sustainable relation between human persons and non-human persons for the well-being of all.

To label Indigenous women's movements as "feminist" is a fraught proposition. Canadian scholar Verna St. Denis explains that formerly "some Aboriginal women argued that feminism was not compatible with Aboriginal culture and nationhood."2 For them feminism seemed to articulate only the needs of white, middle-class women who, focusing on their own oppression, were unresponsive to the needs of women of color in general and Indigenous people in particular. Some made claims that by opposing patriarchal structures and institutions, white women's feminism either ignored or worked against Indigenous sovereignty. They saw gender justice "as being a separate issue from issues of survival for Indigenous people." 3 As

1 Vine Deloria, Jr., Custer Died for Your Sins (1969; Norman: University of Oklahoma Press, 1988), xii-xiii.

2 Verna St. Denis, "Feminism Is for Everybody: Aboriginal Women, Feminism and Diversity," in Making Space for Indigenous Feminism, ed. Joyce Green (Winnipeg: Fernwood Publishing, 2007), 49. Terms conventionally used to refer to Native people differ in the United States and Canada. Canadian authors typically use "Aboriginal" and "First Nation" while scholars writing in the United States use "Indigenous" and "Native."

3 Andrea Smith, "Native American Feminism, Sovereignty, and Social Change," in Making Space for Indigenous Feminism, ed. Joyce Green (Winnipeg: Fernwood Publishing, 2007), 97. 
environmental and social justice actions increase in the Americas, however, more and more women are adopting the term "feminist" although their versions take many forms:

For Native women there is no one definition of Native feminism, rather there are multiple definitions and layers of what it means to do Native feminist analysis. However, as Native feminists, our dreams and goals overlap; we desire to open up spaces where generations of colonialism have silenced Native peoples about the status of their women and about the intersections of power and domination that also shaped Native nations and gender relationships. ${ }^{4}$

Because of its focus on sovereignty that involves both social/gender justice and earth justice, contemporary Indigenous feminism often finds a comfortable home in the world-wide ecofeminist movement. That movement, like Chipko in India and the Green Belt Movement in Africa, works against "the unjustified domination of women, children, people of color, traditional people, poor people and the unjustified domination of nature." ${ }^{5}$ Scholar activist Terran Giacomini identifies ecofeminist activism as resting on three bases: "(i) a recognition that the exploitation of women and nature is central to capitalism, (ii) a stand against that exploitation, and (iii) an affirmation of life-centered alternatives." Although the women of the Black Mesa Water Coalition and the Standing Rock Water Keepers have not publicly identified as feminists, their work fits Giacomini's schema. It is activism of an implicitly feminist kind. Their projects foreground an anti-colonial struggle to re-invest women and Indigenous people in general with the power to protect and sustain the earth. In doing so they call into question the right of nation-states to govern and at the same time promote the understanding that "Nation-states are governed through domination and coercion [while] Indigenous sovereignty and nationhood is predicated on interrelatedness and responsibility." 8

4 Mishuana R. Goeman and Jennifer Nez Denetdale, "Native Feminisms: Legacies, Interventions, and Indigenous Sovereignties," Wicazo Sa Review 24, 2 (Fall 2009), 10.

5 Jytte Nhanenge, Ecofeminism: Towards Integrating the Concerns of Women, Poor People, and Nature into Development (New York: University Press of America, 2011), 98.

6 Terran Giacomini, "Ecofeminism and System Change: Women on the Frontlines of the Struggle Against Fossil Capitalism and for the Solar Commons," Canadian Woman Studies 31, 1-2 (2014): 95.

7 Joyce Green, "Taking Account of Aboriginal Feminism," in Making Space for Indigenous Feminism, ed. Joyce Green (Winnipeg: Fernwood Publishing, 2007), 20. Green gives a particular salient account of the risks associated Aboriginal women take when they identify as feminists.

8 Andrea Smith, "Dismantling the Mater's Tools with the Master's House: Native Feminist Liberation Theologies," Journal of Feminist Studies in Religion 22, 2 (2006), 94. Smith's discussion of Native women's 


\title{
History and Myth
}

Until quite recently, not much had been written about Native American women, as historian Lucy Eldersvel Murphy explains in an article for the Journal of Women's History:

\begin{abstract}
Although scholarship in Native American history has grown substantially in recent years, studies of Native women's experiences have lagged behind. Scholars trained in American Indian history have generally not shown themselves to be adept at using gender as a tool of analysis, even when they notice women, while historians of women, with a few exceptions, have tended to avoid doing ethnohistory - the in-depth research that requires both cultural and historical understanding. ${ }^{9}$
\end{abstract}

Because so much of the historical record was created by European or EuroAmerican men with little access to or understanding of women's roles and activities, racial stereotypes compounded by gender stereotypes, sexism, and ethnocentrism distort our understanding of historical women's lives. ${ }^{10}$ Native women stand, and have always stood, at the intersection of their Native-ness and their Women-ness, their ethnicity and their gender. That intersectionality was impossible for early (male) anthropologists, historians, and settlers to conceptualize. It is not all that easy to navigate now.

In The Sacred Hoop: Recovering the Feminine in American Indian Traditions, Paula Gunn Allen asserts that pre-colonial Native cultures were women-centered. "Traditional tribal lifestyles are more often gynocentric than not, and they are never patriarchal.... American Indians have based their social systems, however diverse, on ritual, spirit-centered, womenfocused world views." ${ }^{11}$ Murphy agrees that "balanced, more egalitarian gender relations [were] typical of most indigenous peoples before they were influenced by European-style patriarchy." 12 "In many tribes, Native American women had spiritual, political and economic power ... at least equal to men." ${ }^{13}$ Federal legislation did much to undo women's power:

spirituality usefully applies to both the Black Mesa Water Coalition and the Water Keepers of Standing Rock.

9 Lucy Eldersveld Murphy, "Native American Women's History: Tribes, Leadership, and Colonialism," Journal of Women's History 17, 4, 124-133.

10 Theda Purdue, ed., Sifters: Native American Women's Lives (Oxford: Oxford University Press, 2001), 3.

11 Paula Gunn Allen, The Sacred Hoop: Recovering the Feminine in American Indian Tradition (Boston: Beacon Press, 1986), 2.

12 Murphy, "Native American Women's History", 126.

13 Denise Lajimodiere, "Native Women and Their Path to Leadership," Wicazo Sa Review 26, 2 (Fall, 2011$), 59$. 
The passage of the Indian Reorganization Act imposed an elected tribal council format that was based on a Eurocentric governmental model, and traditional ways of selecting leaders were wiped out. The Dawes Act... gave tracts of land to male heads of household, further eroding if not completely extinguishing Native American women's role. ${ }^{14}$

Many scholars draw their conclusions about the pre-colonial status of women, at least in part, on an analysis of Indigenous myth since myths often reveal pre-colonial attitudes about gender, gender roles, and sexuality as well as human persons' essential relations with the non-human world. The special strength of mythic history lies in its oral transmission-not just in its Indigenous origins. In the oral tradition, living storytellers transform myths to make them relevant to generation after generation, so the stories live on in meaningful, not just symbolic, ways. The danger, of course, is that a told story may pass away if all those who know it die. On the other hand, the written word and story can live on past the human reader, but it inevitably loses relevance as its language and context ossify. Its value dissolves wholly into the symbolic, or it lends itself to endless cycles of exegesis. Rather than fix Native culture in the past, then, the updating and retelling of myth continuously refreshes cultural knowledge and world view and works to keep Native-ness present and vital.

Girls and women in Native myth variously function as creators, embodiments of the sacred, and culture-bringers. Even a quick retelling of some of these narratives - from the arid canyon lands of the Southwest near Black Mesa as well as from the prairies of the Lakota-shows women's power to serve as a kind of connective tissue, linking together, through story and ritual, human persons and non-human persons. It is this power to bring together, to connect and make whole, that contemporary Indigenous ecofeminists embody today.

From the Keres of Laguna and Acoma Pueblos in New Mexico comes Kochinnenako, Yellow Woman, one of the four Corn Sisters. Although details change with various versions of her story, Yellow Woman consistently establishes (or re-establishes) the subsistence contract through a sexual liaison with the non-human world, often a male nature spirit such as Whirlwind Man or the Thunder Kachina. Their union ensures the tribe's survival. 
The patriarch of modern anthropology, Franz Boas notes that in these stories "a woman is usually abducted by a dangerous Kachina when she goes to draw water... The Kachina places her jar upside down by the water" and takes her away. ${ }^{15}$ In some versions Yellow Woman is smitten by the beauty of a Kachina and willingly leaves with him. She returns some months later, often with twin boys, or pregnant with them.

In the story of Yellow Woman and Buffalo Man, Yellow Woman is married to Arrow Boy but falls in love with Buffalo Man. Arrow Boy tries to get her back, shoots Buffalo Man, and then shoots Yellow Woman too when she grieves for Buffalo Man - not in rage, but because he wishes to re-unite the lovers in death. Because Yellow Woman loves Buffalo Man, the buffalo people agree to give themselves to the humans. Her sacrifice confirms human and non-human interrelations, and the people thrive..$^{16}$ Yellow Woman "becomes a symbol of renewal through liaison with outside forces." ${ }_{17}$

While Yellow Women's sexuality-her wildness within-enables her life-giving relations with the Kachina - the wildness without - for the Lakota, White Buffalo Calf Women's sexuality does not constitute her power, even though in the end she brings blessings and renewal to the Lakota People. ${ }^{18}$ " $[\mathrm{H}]$ er teachings include walking in humility, respecting mother earth, valuing and protecting women and children, and living in harmony with all things." 19

Richard Erdoes and Alfonso Ortiz collected the following White Buffalo Calf Woman story from John Fire Lame Deer, 'a famous Sioux 'holy man,' grandson of the first Chief Lame Deer, a great warrior who fought Custer."20 As John Fire Lame Deer tells it, one summer long ago White Buffalo Calf Woman appeared to two young hunters sent out to find food for the starving people at the encampment of the seven sacred council fires of the Lakota Nation. She wore a white buckskin dress, "tanned until it shone a long way

15 Franz Boaz, ed., Keresan Texts, volume VIII, part 1 (New York: Publications of the American Ethnological Society, 1928), 276-77.

16 A. Lavonne Ruoff, "Ritual and Renewal: Keres Traditions in Leslie Silko's 'Yellow Woman'," in "Yellow Woman”: Leslie Marmon Silko, edited by Melody Graulich (New Brunswick: Rutgers University Press, 1993), 73 .

17 Ibid., 74.

18 Patricia Smith and Paula Gunn Allen, "Earthly Relations, Carnal Knowledge: Southwest American Indian Women Writers," in “Yellow Woman”: Leslie Marmon Silko, edited by Melody Graulich (New Brunswick: Rutgers, 1993), 125.

19 Scott Leonard and Michael McClure, Myth and Knowing (New York: McGraw Hill, 2004), 125.

20 Richard Erdoes and Alfonso Ortiz, American Indian Myths and Legends (New York: Pantheon, 1986), 52. 
in the sun" and carried a large bundle and "a fan of sage leaves." ${ }^{21}$ She was "lila wakan" - very holy. One of the young hunters could not control his desire for her, but when he reached out his hand to touch her, he was "suddenly covered by a cloud, and within it he was eaten up by snakes that left only his skeleton, just as a man can be eaten up by lust." ${ }^{22}$ She told the other scout that she would visit his people soon. In four days she came to the encampment and gave to chief Standing Hollow Horn chanunpa, the sacred pipe, and taught them how to use it. "With this holy pipe," she said, "you will walk like a living prayer."

With your feet resting upon the earth and the pipe stem reaching into the sky, your body forms a living bridge between the Sacred Beneath and the Sacred Above. Wakan Tanka smiles upon us, because now we are as one: earth, sky, all living things, the two-legged, the four-legged, the winged ones, the trees, the grasses. Together with the people, they are all related, one family. The pipe holds them all together.... The pipe is alive; it is a red being showing you a red life and a red road. ${ }^{23}$

As she walked away from camp, buffalo in great herds appeared, allowing themselves to be killed so that the people might survive. ${ }^{24}$ In this way White Buffalo Calf Woman made traditional Lakota life and culture possible.

After contact with Europeans and Euro-Americans, the sacred subsistence contract embodied in these women-centered myths was broken, of course. On Native lands, unparalleled ecological disaster followed, perhaps first and most horrifyingly in the purposeful slaughter to near extinction of the buffalo people at the end of the $19^{\text {th }}$ century. Since then, Native people and their lands have suffered with a vengeance, through the toxic pollution of land, air, and water; through the destruction of forests and watersheds, and grazing lands; through the exhaustion of soil and ground water and the disappearance of fish, animals, birds, and the habitat they need for survival. Women and girls have suffered too-from the colonizing culture and its patriarchal institutions as well as from their own cultures' adopted misogyny.

But some traditions are strong; some stories echo down through the ages. And so in the last few decades, Native girls and women have taken the lead in rejecting the false choice between prosperity and sustainability and are

21 Leonard and McClure, Myth and Knowing, 134-35.

22 Ibid.

23 Ibid, 136.

24 Ibid, 132-37. 
bringing their communities together, as their mythic mothers did, to protect and restore the land and the right relation between humans and non-humans that has been their business all along. Their ecofeminist activism has spread throughout Native America, and their many organizations have had success, as Winona LaDuke explains:

Despite our meager resources, we are winning many hard-fought victories on the local level. We have faced down huge waste dumps and multinational mining, lumber, and oil companies. And throughout the Native nations, people continue to fight to protect Mother Earth for future Generations. Some of the victories include... a moratorium on mining in the sacred hills of Northern Cheyenne, Blackfeet, and Crow territory; an international campaign that stopped the building of mega-dams in northern Canada; the restoration of thousands of acres of White Earth land in Minnesota; and the rebuilding of a nation in Hawai' ${ }^{25}$

Among these actions, two stand out: the Hopi and Navajo Black Mesa Water Coalition in the Southwest and, most recently, the Standing Rock Water Keepers action to stop the completion of the Dakota Access Pipeline.

\section{Black Mesa Water Coalition}

Black Mesa is a four thousand square mile plateau in northern Arizona. Twenty-one billion tons of low-sulfur coal, the largest deposit in the United States estimated at a value of $\$ 100$ billion, lie just below the surface. The Mesa is home to sixteen thousand Navajos and eight thousand Hopis, the Hopi lands completely surrounded by the larger Navajo domain. ${ }^{26}$ Further down below the coal, rests the Navajo Aquifer, a subterranean pool of pure ice-age water, the source of life for humans and non-humans on the desert reservations..$^{27}$ Like so many colonized peoples around the world who suffer from the "curse of oil," the fossil fuel riches of the Navajo and Hopi homeland have nearly been their undoing. For Indigenous peoples, it is not good to have something someone else wants.

In 1966 after forty years of manipulation by government and energy in-

25 Winona LaDuke, All Our Relations: Native Struggles for Land and Life (Cambridge, MA: South End Press, 1999), 4. For an updated discussion of Native American Women's earth activism, see LaDuke's: Stories from the Front Lines in the Battle for Environmental Justice (Winnipeg: Spotted Horse Press, 2016).

26 Tim Folger, "A Thirsty Nation," One Earth Magazine (Fall 2004), http://wwwnrdc.org/onearth/o4fall/blackmesa1.asp.

27 Vernon Masayesva, "Black Mesa Trusts Applauds Decision to Shutter Navajo Generating Station," Black Mesa Trust. http://www.blackmesatrust.org/. 
terests keen to use Black Mesa coal to fire the growth of Southwest desert cities such as Las Vegas, Phoenix, Los Angeles, and Tucson, both the Hopi and Navajo tribal councils secretly signed agreements leasing sixty-five thousand acres on Black Mesa to the Peabody Coal Company of Kentucky, then the largest coal producer in the United States. The leases ran for thirtyfive years and were renewable for another thirty-five. Outraged Navajos tried to block the mining equipment by setting up barricades in the road. Traditional Hopis sued their own tribal council. The deal violated every guideline that the Department of the Interior had set up for leasing on public lands: competitive bidding did not happen; the agreement contained no automatic renegotiation clauses; and Peabody paid a fixed rate rather than a percentage royalty rate. "At a time when water rights in the Southwest cost $\$ 50$ per acre-foot, the Hopi got $\$ 1.67$ per acre-foot. The Navajo got $\$ 5$ per acre-foot. At the time the royalty rate on public lands for coal mining was $\$ 1.5$ per ton. The Hopi and Navajo split a rate of 37 cents per ton." ${ }^{28}$ The lease provided few environmental safeguards, and worst of all, Peabody was permitted to pump four thousand acre-feet (approximately a billion gallons) of water a year out of the Navajo Aquifer for its mining and transportation operations. ${ }^{29}$ Announcing the leases in 1966, Interior Secretary Stewart Udall promised "[n]ew jobs, large tax benefits, and tremendous economic advantages - not only for the two Indian tribes - but for the entire southwest'." ${ }^{30}$ Coal from the new mines would go to a consortium of twenty utilities called WEST (Western Energy Supply and Transmission) designed to power up the urban Southwest. The cities got their exponential growth, their air conditioning, their neon lights, their golf courses, and their fountains spraying precious water into the bone-dry desert air. Corporations, developers, and politicians made their fortunes. The Hopi and the Navajo did not. They remain some of the poorest people in the United States. Only about one half of their homes have running water or electricity.

Peabody opened two strip mines on their leaseholds, the Black Mesa mine and the Kayenta mine. Workers literally ripped the land apart, peeling off topsoil and underlayment to expose the coal that they then dynamited

28 Judith Nies, Unreal City: Las Vegas, Black Mesa, and the Fate of the West (New York: Nation Books, 2014), 52 .

29 Donald A. Grinde and Bruce E. Johansen, Ecocide of Native America: Environmental Destruction on Indian Lands and Peoples (Santa Fe: Clear Light Publishers, 1995), 141.

30 Quoted in Nies, Unreal City, 115. 
into movable chunks. Vegetation died, the air filled with black dust, and toxins poisoned the irreplaceable Navajo Aquifer. Soon after the mining started, deadly green water seeped into pockmarks left on the Mesa. Navajo sheep that drank that water at noon were dead by suppertime. ${ }^{31}$

Once extracted from Black Mesa, the coal had to be transported to power generating stations. Having failed to negotiate a rail system, Peabody decided to use a coal slurry pipeline. In a slurry system the mined coal is mixed with water and then sluiced through a pipeline to its destination, the whole process taking enormous amounts of water. Peabody contracted with the giant global construction company Bechtel to build its coal slurry pipeline running 273 miles - uphill - from Black Mesa to the Mohave Generating station in Leighton, Nevada, another of Bechtel's projects. The Mohave station provided electricity to Las Vegas, Los Angeles and other far west cities. Coal slurries are everywhere considered a disastrous waste of water, and Peabody's became the only one operating in the United States. To slurry its coal, Peabody pumped a billion gallons a year for more than forty years from the Navajo Aquifer. In these decades, groundwater levels dropped, wells, springs, and seeps dried up, and the entire ecology of Black Mesa collapsed. The land reclamation Peabody promised proved impossible since in areas that receive fewer than 10 inches of rain a year, plants simply won't grow back in the destroyed earth. ${ }^{32}$

Four years after the Mohave plant opened in 1970, a second Bechtel plant, the Navajo Generating Station near the northern rim of the Grand Canyon, came on line. Coal from the Kayenta mine, also on Black Mesa, travels by rail to the Navajo Generating station to produce electricity for the Sonoran desert cites of Phoenix and Tucson. Corporate planners figured that the two generating plants combined would require twelve million tons of Black Mesa coal a year, so Peabody needed to expand its Black Mesa operation. The thousands of Navajos who lived on the Mesa, like many other Indigenous people before them, would have to be removed.

Claiming to help settle a largely fictive land dispute between the Hopi and the Navajo, Peabody lobbyists convinced the U.S. Congress to pass legislation dividing Black Mesa and conveniently giving almost a million acres to Hopi people who lived far away from the mining sites. Navajo resi-

31 Ibid, 37.

32 Winona LaDuke, Recovering the Sacred: The Power of Naming and Claiming (New York: South End Press, 1999; reprint Chicago: Haymarket Books, 2005), 42. 
dents who had lived on the land for generations became trespassers, and the government, not the mining company, had to pay for their removal. In 1974, the Navajo removal began along with the slaughter of their sheep flocks. Separated from their lands, many died of alcoholism and despair.

The people did respond.

On October 13, 1974, armed members of the American Indian Movement [AIM] marched past the security guards at Black Mesa Mine No. 1 and sat down before one of the mine's massive drag shovels. When the operator refused to stop the shovel, one AIM member fired at him, the bullet lodging in the cab of the shovel. The occupiers issued a set of demands, most of them revolving around Peabody's lack of attention to local concerns. ${ }^{33}$

The protestors refused to meet with Navajo tribal government, stating "'we have little time for tribal governments that don't protect their people." "34 After a week, Peabody made promises to start listening to people's complaints, put a moratorium on new road building, and compensated shepherds for killed sheep. The AIM members left the mine, "but with an increased reputation for standing up for the interests of local Navajos and demonstrating that energy development could, at least temporarily be halted." 35 "Temporarily" is the operative word here.

After AIM's direct action, the Navajo and their allies came to Congress to protest the removal, but no one listened. Peabody Coal had by then become part of a very powerful corporate/government family that included the incredibly well-connected Bechtel. Bechtel's former president George Schultz was Secretary of State; its former legal counsel, Caspar Weinberger, was Secretary of Defense; and former director of Bechtel Nuclear, Ken Davis, was Assistant Secretary of Energy. The president of Peabody Coal served on Reagan's Energy Advisory Board. The Navajos did not have a chance.

In 1989, when the Peabody leases needed renewal, hundreds of Navajo and Hopi testified about the negative effects of mining on their lands. Thousands of years of water had been used up in a few decades. "The water has become more valuable than the coal," explained Hopi activist Marilyn Masayesva at the government's environmental hearings. "The water is

33 Andrew Needham, Power Lines: Phoenix and the Making of the Modern Southwest (Princeton: Princeton University Press, 2014), 242.

34 Ibid.

35 Ibid. 
priceless. No amount of compensation can replace the source of life for the Hopi and Navajo people." ${ }^{36}$ Incredibly, the George W. Bush administration renewed the Peabody lease "for the life of the mine" and even increased the allowed draw down from the aquifer. And so Los Angeles and Phoenix boomed; Las Vegas remained an oasis playground in the Mohave; and much of Black Mesa died of thirst.

In 2001, in response to a report about Peabody's dangerous drawdown of water from the Navajo Aquifer, a small group of Hopi and Navajo college students - mostly women-led by Enei Begate Peter and Wahleah Johns, formed Black Mesa Water Coalition (BMWC). They dedicated the Coalition to addressing issues of water depletion, natural resource exploitation, and public health within the Navajo and Hopi communities, especially on Black Mesa. They centered their mission on the Diné word Hózhó for "walking in beauty-living in a manner that strives to create and maintain balance, harmony, beauty and order." 37 They had plenty to do. They "supported and worked with partners in the Black Mesa region to educate Navajo communities and mobilize them to force the tribal government to stop Peabody's use of the N-Aquifer for the slurry line." 38 That strategy at first didn't work - the tribal government wasn't easy to force. But the Coalition organized protests of young mothers and children and grandmothers. They allied with other groups working on similar problems, both on the local and national levels.

In December of 2005 the Coalition and its partners at last defeated Peabody and Bechtel and accomplished the shutdown of the slurry pipeline. A lawsuit brought by them won stricter emission controls for the Mojave Station as well, considered the most polluting facility in the country. Bringing the old power plant up to Environmental Protection Agency requirements proved too costly, and so the WEST power consortium finally closed it. A short documentary on the BMWC's website shows the tall main stack outlined against the blue sky, collapsing in slow motion and falling to rubble on the desert floor. Hopi and Navajo activists cheer its passing. With no destination for its tons and tons of coal, Peabody closed its Black Mesa Mine. BMWC had, in four years of hard, smart, community-based work, brought

36 Quoted in Nies, Unreal City, 54.

37 Black Mesa Water Coalition, "No Coal and Environmental Justice Program,"

http://www.blackmesawatercoalition.org/no-coal-and-environmental-justice.

38 Black Mesa Water Coalition. 
down the corporate/government giant. In January 2010, they sued for and won the revocation of Peabody's life of the mine permit for Black Mesa. In April of 2016, Peabody Energy reported a loss of 2 billion dollars in the previous year and filed Chapter 11 bankruptcy. ${ }^{39}$

From its start, BMWC faced a gendered challenge from male dominated tribal councils - the official governing bodies of the Navajo and Hopiwho have consistently supported and disproportionately benefitted from coal mining operations. Back in 1966 they signed the leases that opened up Black Mesa to exploitation in the first place. Adopting the colonizers top-down patriarchal "leadership" system-even in these traditionally women-centered cultures - the male governing structure rejected BMWC's demands to stop the leases that permitted the drawdown of the Navajo Aquifer. The upstart, grass-roots NGO, run by young women, threatened to end the lucrative privilege they had enjoyed for so long. But the BMWC established relationships with other local sovereignty and environmental justice groups and then with national and international environmental organizations. They educated young people, and they connected with tradition elders who had always distrusted the tribal councils. They organized demonstrations and protests and testimonies. They hired lawyers, young Native women like themselves, to argue their cases in court. They enlisted volunteers and, perhaps most importantly, advocated for new ways of combining traditional land-based values with innovative, contemporary technologies. Like women-led social and environmental justice organizations around the world, they fostered development projects that benefit everyone-human and non-human alike. All the while they refused the binary logic of winners and losers by advocating for a just transition away from the deadly extractive economy. They refused to leave anyone behind, especially advocating for young people by developing ventures that gave the up-coming generation opportunities to stay on their homelands and work for a prosperous and intact Indigenous future.

Today BMWC facilitates Navajo and Hopi joint organizations and projects to combat environmental injustice across the Navajo Nation and Hopi and throughout North America, as the website explains:

39 Chris Mooney and Steven Mufson, "How coal titan Peabody, the world's largest, fell into bankruptcy." The Washington Post (3 April 2016),

https://www.washingtonpost.com/news/energy-environment/wp/2016/04/13/coal-titan-peabody-energyfiles-for-bankruptcy/?utm_term=.46fed1df5144. 
Because BMWC's founders were raised to value our culture, and trained in the environmental justice movement, we know we must break our dependence on the fossil fuel industry to realize our true potential. The sub-goals of the No Coal \& Environmental Justice Program are to: hold Peabody Coal Company accountable for the damage done to Black Mesa's water, environment, and community health; to replace Black Mesa's coal complex with renewable energy; and to instill polices that promote a just transition for Black Mesa and the Navajo Nation. ${ }^{40}$

To that end, the Coalition established The Restorative Economy Program, The Navajo Wool Market Improvement Project, and The Food Sovereignty Project. All three bring young people together with traditional elders to cultivate "an economy that benefits our people, strengthens our culture, and returns the term 'economy' to its original meaning - the management of home." ${ }^{41}$ The Coalition continues its educational outreach in high schools and the Navajo Community College and has established the Southwest Indigenous Leadership Institute that focuses on grass-roots organization and movement building.

The Coalition, along with the Hopi Foundation, is also helping develop community-owned companies to produce both wind and solar energy and even looking forward to industrial-scale expansion. ${ }^{42}$ Its Solar Project may have the greatest impact for the future well-being of Black Mesa and its peoples, representing a first step towards a just transition away from a fossil fuel dependent economy.

This green economic development work was bolstered in July 2009, when BMWC founded the Navajo Green Economy Fund and Commission within the Navajo National government. In 2013 the Coalition secured from the California Public Utilities Commission a fund which uses revenues from the sale of sulfur dioxide allowances from the shut-down of the Mohave Generating Station to pay development grants for renewable projects that benefit the Hopi Tribe and Navajo Nation. These funds help support its sustainable development projects.

According to co-founder Enei Begate Peter,

[a] green economy is nothing new to Indigenous peoples. We have been practicing this way of life in harmony with Mother Earth before there was a Wall Street. But today, what we strive to do is unite the modern

40 Black Mesa Water Coalition.

41 Ibid.

42 LaDuke, All Our Relations, 187-96. 
non-polluting technologies, such as wind and solar, with the traditional technologies, such as weaving and farming, and with that unity we can open up new doors of opportunity for ALL our people-young and old, college educated and land educated alike. ${ }^{43}$

The success of the Black Mesa Water Coalition rests at least in part on their refusal to accept the forced choice between environmental justice and economic survival and their promotion of sustainable economic renewal in keeping with traditional earth-based values. Their return to the values of their grandmothers appeals to traditionalists and elders in both tribes and brings together the wisdom of the old with the innovative energy, education, and technical savvy of the young. Mostly women, young and old, make up these collaborative networks. They are used to acting for the good of the people and for the good of the land. Like their mythic cousin Kochinnenako, they have become the living link between the people and each other, reconnecting them to the land, the wellspring of their cultural identity. Moving cultural values into the $21^{\text {st }}$ century (but leaving out the sex), a wind turbine is their Whirlwind Man, the recharging Navajo Aquifer their Thunder Kachina, and the Sun the ultimate source of energy as it has always been. Largely thanks to them, Black Mesa has a green future. The Black Mesa Water Coalition is an example of ecofeminist activism at its most successful.

\section{The Standing Rock Water Keepers}

While the women of the Black Mesa Water Coalition lead in their Hózhó way, they oppose one of most powerful and dangerous forces operating today - the fossil fuel industry. Terran Giacomini urges an understanding of "extractivism as a form of violence toward women and children. It is part of rape culture and it is a continuation of colonization. It is the commodification of the natural world, and it is destroying us."44 The Water Keepers at Standing Rock took on that fight as well as they tried to stop the Dakota Access Pipeline from being finished.

The Dakota Access Pipeline (DAPL) stretches underground 1,172 miles from the Bakken shale oil fields in northwest North Dakota, through South Dakota and Iowa, and terminates at an oil tank farm near Patoka, Illinois. 
Dakota Access, a Houston based company and a subsidiary of Energy Transfer Partners, is building the pipeline. The $\$ 3.78$ billion project was announced to the public on June 25, 2014, and informational hearings for landowners took place between August 2014 and January 2015. With the completion date set for January 1, 2017, the project was $87 \%$ completed on November 26, 2016. Pipeline construction did create a number of jobs, but Energy Transfer Partners estimates that only 12 to 15 permanent employees will be needed to maintain the pipeline, most of them working in Iowa.

Supporters argue that the pipeline provides a more reliable method of transport to refineries than rail or road and that it will improve the overall safety of oil transportation. Data does not support that claim. ${ }^{45}$ Now $70 \%$ of Bakken oil is transported by rail, and everyone agrees that pipeline transport will be cheaper. Supporters also claim that oil from the Bakken fields will help the United States attain energy independence. But after a 40-year ban on the exportation of U.S. crude (excepting Alaskan crude which has always been refined in Asia), the Congress recently allowed its export once again. It's difficult to imagine how North Dakota crude, refined in Japan or China and then shipped back to the United States for sale, can promote "energy independence." 46

Dakota Access originally proposed laying the pipeline near the mostly white city of Bismarck, North Dakota, but the Army Corps of Engineers rejected that route when Bismarck residents opposed having the pipeline threaten their water supply. The route now crosses 90 feet under the Missouri River at Lake Oahe, 500 feet from the Standing Rock reservation. This willingness to expose Native people and their homelands to environmental risks unacceptable for non-Native people follows the common racist pattern. As Winona LaDuke explains, "today [Native] lands are subject to some of the most invasive industrial interventions imaginable." LaDuke catalogues a few:

Reservations have been targeted as sites for 16 proposed nuclear waste dumps... Seventy-seven sacred sites have been disturbed or desecrated through resource extraction and development activities. The federal government is proposing to use Yucca Mountain, sacred to the Shoshone, as a dumpsite for the nation's high-level nuclear waste. Over

45 David Biello, “Are Pipelines Safer Than Railroads for Carrying Oil?," Scientific American (July 10, 2013), https://blogs.scientificamerican.com/observations/are-pipelines-safer-than-railroads-for-carrying-oil/.

46 "Light, Sweet Compromise," The Economist,

http://www. Economist.com/news/finance-economics21684531-light-sweet-compromise. 
the last 45 years, there have been 1,000 atomic explosions on Western Shoshone land in Nevada, making the Western Shoshone the most bombed nation on earth. ${ }^{47}$

Facing the possibility of a potentially disastrous oil spill into the Missouri River, First Nations people from around the world and other environmental activists, in April, 2016, began a direct-action protest encampment on the Reservation near Lake Oahe at the confluence of the Cannon Ball and Missouri Rivers. Led by women calling themselves Water Protectors/Keepers, they bitterly opposed the pipeline. They fear a pipeline leak would destroy the tribe's only source of drinking water and contaminate the supply for millions of people who live downstream. The Water Protectors also tried to preserve cultural and religious landmarks throughout the area, some already destroyed by pipeline construction.

The Water Protectors direct-action at Standing Rock and the Black Mesa Water Coalition have much in common. Both are led by women, both fight against the huge transnational fossil fuel industry and the government structures that serve its corporate interests; both work for tribal and environmental justice. But in other ways the two movements could not be more different. They arose in profoundly different cultures, different circumstances, and different regions. They publicly position themselves in almost opposite ways. Black Mesa Water Coalition, and the stories about it in the media, hardly mention the fact that women lead most of its projects while the Standing Rock Water Protectors organized explicitly around an inspirational and tradition-based understanding of Indigenous womanhood. Yet as the two movements bring together Native and non-Native groups from all around the world, a common enemy emerges: the relentless and ruthless corporate/governmental drive for power and profit above all else. And so these movements take their places alongside similar women-led and women-centered movements for social and environmental justice around the world that "fundamentally challenge the colonial and capitalist status quo." 48

While the Black Mesa Water Coalition, originating in an academic setting and led by college students, has for sixteen years strategically planned its many grassroots actions, legal battles, and development projects, the

47 LaDuke, All Our Relations, 2-3.

48 Andrea Smith, "Native American Feminism, Sovereignty, and Social Change," Feminist Studies 31, 1 (Spring 2005), 125. 
Water Protectors' attempt to thwart the Dakota Access Pipeline was by all accounts a happy kind of direct-action chaos. Throughout the spring and summer of 2016 various encampments sprung up like prairie flowers. At last more than 10,000 people-Native and non-Native alike-some from as far away as Tibet, Sweden, Guatemala, and Brazil and from nearly every one of the United States, including Hawaii and Alaska, camped on the Reservation and surrounding public lands, coming and going as their other responsibilities dictated. Many brought their horses with them.

As the camps grew over the summer, they evolved into a complex economy, with teams of sawyers; a free medical corps, which included acupuncturists, masseuses, herbalists, and prescription-writing MDs; and a team of chimney sweeps who cleaned out the flues of the ubiquitous wood stoves installed, gratis, by volunteer construction crews. Central to all, of course, were volunteer chefs such as Rachel Wheatley, a Maidu from near Orrville, California. Wheatley was a long-haul trucker before she arrived at Standing Rock. In the summer her kitchen had served 600 a night. ${ }^{49}$

Music, drumming, and prayer continually circled the tents and yurts and trailers. Every day through the summer and fall, various groups, some in traditional dress, paraded to pledge their support for the movement-not only to protect Indigenous people's rights and the lands they inhabit, but also to protect the earth and combat global climate change.

The Standing Rock movement sought to halt, and even reverse, the "settler colonialism" that has displaced, replaced, and in many cases wiped out Indigenous peoples and cultures in the United States for hundreds of years and usurped their homelands. As Potawatomi scholar-activist Kyle Powys Whyte explains,

[s]ettler colonialism refers to complex social processes in which at least one society seeks to move permanently onto the terrestrial, aquatic, and aerial places lived in by one or more other societies who already derive economic vitality, cultural flourishing, and political self-determination from the relationship they have established with the plants, animals, physical entities, and ecosystems of those places. ${ }^{50}$

49 Emily Arasim and Osprey Orielle Lake, "15 Indigenous Women at the Frontlines of the Dakota Access Pipeline Resistance," Women's Earth and Climate Action Network (29 October 2016), http://www.ecowatch.com/indigenous-women-dakota-access-pipeline-2069613663.html.

50 Kyle Powys Whyte, "The Dakota Access Pipeline, Environmental Injustice, and U.S. Colonialism," Red Ink: An International Journal of Indigenous Literature, Arts, and Humanities (January/February, 2017), 4. https://papers.ssrn.com/sol3/papers.cfm?abstract_id=2925513. 
The groups moving into the already occupied lands, the invaders, we call "settlers"; the invaded, in this context, we call "Indigenous peoples."

As women-centered Indigenous myth reminds us, Native people's explicit identity derives from their precise inter-relationships with their homelands - the "plants, animals, physical entities, and ecosystems of those places." While those complex and profound connections constitute individual and group selfhood and survival, they also embody the sacred. At the time of contact with Euro-Americans, the sacred homeland of the Lakota/Dakota/Nakota people who now live at Standing Rock included huge swathes of the Great Plains stretching from modern day North Dakota, South Dakota, Minnesota, Iowa, Wyoming, and Montana and into Canada-all the way to the foothills of the Rocky Mountains. Here, White Buffalo Calf Woman taught the Lakota how to dance for the Sun and keep their subsistence world in perfect balance. Through military actions, massacres, broken treaties, animal extinctions, laws and policies so unjust they defy description, religious oppression, forced sterilization, and boarding-school terrorism, the United States government-and its army of settlers - has today corralled the Lakota/Dakota/Nakota people into a number of small reservations in North Dakota and South Dakota. That their cultural identity has survived such a vicious and systematic onslaught attests to their incredible resilience and, perhaps, to their sacred bonds with the non-human world. LaDonna Brave Bull Allard, who founded the Sacred Stone resistance camp in April, sums up the peoples' centuries-old struggle: "We must remember we are part of a larger story. We are still here. We are still fighting for our lives on our own land." 52

The Dakota Access Pipeline, as it tunnels its oily "blacksnake" beneath the bed of the Missouri River, threatens this identity-forging bond because it threatens the River, the source of life for the land and its People. As one small link in the chain of the climate-altering, worldwide fossil-fuel dependency, the pipeline and the oil extraction industry it services threaten Earth, the Mother herself. For a People whose survival system-cultural, physical, and spiritual - depends on sacred connection with the land, what could be more devastating?

51 Ibid.

52 LaDonna Brave Bull Allard, "Why the Founder of Standing Rock Sioux Camp Can't Forget the Whitestone Massacre," YES! Magazine, http://www.yesmagazine.org/people-power/why-the-founder-of-standingrock-sioux-camp-cant-forget-the-whitestone-massacre-20160903. 
The Standing Rock Indian Reservation straddles south-central North Dakota and north-central South Dakota. The Canon Ball and Missouri Rivers come together to form the northern arrow-head of Reservation land. The tribes living there include "bands of the Hunkpapa and Siha Sapa of the Lakota Nation, and the Hunkpa and Cuthead bands of the Dakota Nation, and Yanktonai grouped under the Nakota." ${ }^{53}$ A legend told by the Arikara (or Ree) tribe explains the origin of Standing Rock. In the story a woman, angry with her husband because he had taken a second wife, refused to go with her band when they broke camp early one morning. She sat down on the ground with her baby on her back and, some say, her dog beside her. By noon the husband feared that she might despair and take her own life, and so he sent his two brothers back to bring her along. When they got to the old camp, they called to the woman. "Sister-in-law, get up. We have come for you. The camp awaits you." She did not move or answer, and when they touched her head, they found that she had turned into stone. The band considered the stone wakan (holy) and decorated a travois and a pony to transport it from camp to camp as they moved. The Standing Rock Reservation was named for the stone woman, baby on her back, who refused to leave. Her figure stands there today. ${ }^{54}$

Like her, the Water Protectors stood fast. Mythic themes of cultural survival and sacred connection, of ancestors and as-yet-be-born-children, of water, earth, and blood, flow through the language of the many powerful women, young and old. That language molds their particular brand of ecofeminism - their Tribe if you will. "With conviction and care, the women convey that protecting water and sacred places has always been their traditional role as women, and they are taking a fierce stand to ensure a healthy life for generations to come. ${ }^{\prime 5}$ In interviews, many of them equate the respect for women with the respect for Earth and water: "We know that we come from the water, the first environment is this water, and the women carry that. We carry that water inside of us. And this is about connection.... It is time for all people of all nations to wake up and listen to the water. Water is life." $" 56$

53 Donovan Arleigh Sprague, Images of America: Standing Rock Sioux (Charleston, South Carolina: Arcadia Press, 2004), 4.

54 Ibid., 9.

55 Arasim and Lake, "15 Indigenous Women."

56 Deezbaa O'Hare quoted in Arasim and Lake, "15 Indigenous Women." 
Rose Tompkins, Red Day Woman, a Standing Rock land owner of Hunkpapa, Sisseton and Yankton heritage from the Assiniboine Sioux reservation in Montana, ran one of the six kitchens at the encampment. By her own admission a "real good cook," she came to Standing Rock in mid-August and stayed through February, working out of her tiny trailer kitchen to prepare hundreds of meals a day. At first she fed only elders, but by October she welcomed anyone who wanted to eat. She used mostly donations of traditional foods like wild rice, venison, elk, salmon, and wild turnip.

The author interviewed Rose Tompkins on April 20, 2017, in Columbia, Missouri, where she came to speak to a group of college students studying the direct action at Standing Rock.

Author: Tell me about what you did at Standing Rock, why you thought you should go there, and what happened.

Rose: My purpose to be there was to stand in solidarity with everybody else and to stay in prayer. That was my most important thing... I was going through a lot in my life at the time. I told myself that strength and patience was something I really needed to work on. In the end, it came out to be patience and then having all my strength, but it was well worth it.

Author: How did you do that work? Just on your own or did you do it collectively?

Rose: You know what? It just kind of happened. I didn't realize it until maybe around January. I was busy running my kitchen, but as time went on, I started listening more instead of speaking a lot. I am a quiet person in some ways. During that time of being quiet and going to the front lines where there was a lot of disturbing violence and stuff like that, I became more appreciative. I became more humble. I became more aware of what was going on. I think that's what kind of developed my strengths. It developed my patience because I felt like I had to be patient. I couldn't rush things. Being in camp was such a spiritual awakening for me. I couldn't rush anything. Everything came to me when it was time to come to me.

Author: I've read lots of comments from women who were in leadership positions, at least the media reports it that way, and they were saying, all of them, that being a woman was part of this. I'm particularly interested in that.

Rose: I believe the way that I was raised, my traditional morals and 
values by my ancestors, that Native women, all women, are the backbone of the family. We believe that we're so connected with the Mother Earth... We believe that Native women are so in tune within ourselves and with the Mother Earth that it's sacred. We're the ones that give the compassion, the strength. We give the wisdom. It's so spiritual. In many ways the women stand strong... as far as their spirituality and their wisdom. When this thing came together in Standing Rock, I felt proud to be part of it going into the sweats [sweat lodges] and the ceremonies with these women from all over the world.

Author: From all over the world.

Rose: All over the world, and we all felt the same... It was very awesome. It was a prayer camp, so we were constantly praying all the time. We thought about all the people that are out there that need help. We thought about spreading our awareness. We prayed for the water. Do you know how important water is to us?

Author: There must have been a huge contrast between that spirituality and what was happening out on the front lines with the tanks and the police and the pepper spray. Did you ever have bad encounters with the police?

Rose: Yeah. The Red Warriors had put straw bales across the road. I went up there, and I walked straight up to the front lines because I could hear the police on the other side. I'm not just talking about two or three cop cars. I'm talking about Humvees circling us, surrounding us, trying to get us all closed in so they could take us all down. When I got there, the police officer was saying, "You guys need to take these straw bales down," this and that... Me and my friend, we decided to just leave. Right when we were leaving, people were coming... The next thing we know, people are screaming and running. The police officers had tanks of tear gas. We got sprayed in our faces. My friend got hit with a baton and fell. We couldn't see. We could hear people screaming and yelling. We took off running. We held on to each other. Somebody slipped and fell. We picked them up and brought them with us. Somebody else fell in a hole, and we picked them up. At one point I turned around and I saw one of the police officers pulling one of our ladies out of the sweat lodge by her hair. It was so emotional to see that.

Author: Pulling her out of the sweat lodge? 
Rose: I felt like I was running for my life. We couldn't see. We didn't know where we were going... All we could hear was footsteps behind us, and we wanted them to stop. What came to my mind was the Wounded Knee Massacre, when a long time ago they took the Indians and they ran them and ran them until they fell into this great big ditch. Then they shot and killed everybody, the women and children. The river was not that far from where we were. What went through my mind was, "They're going to chase us to the river, and they're going to kill us. That's what they're going to do." Well, we stumbled and ran and ran and ran. We were not even a half a mile from our camp, the Oceti camp, and we were lost. It took us five and a half hours to walk back to camp... We were crying because we just felt like we were in a fricking war with our own government, with our own people.

Author: How do you feel about it now?

Rose: [Before we left in February] a lot of us women got together, and we talked about it like, "You know what? This is just the beginning. We all have to stand strong. It's up to us, as women, to be the backbone for the rest of the people in the world... We need to gain that world peace. We need to tell people, wake them up. Get out there and wake people up." I believe we can find many ways to take care of our Mother Earth and heal her.

Although in the end, the Water Protectors could not save "our Mother Earth" from the raw exercise of government-corporate power, the Standing Rock movement did have some victories. On November 1, 2016, President Obama announced that his administration had been in contact with the Army Corps of Engineers to examine the possibility of rerouting the pipeline to avoid lands that Native Americans hold sacred. On November 14, 2016, the Corps announced that it was going to seek out additional analysis and discussion. On December 4, it refused to grant an easement for the pipeline to be drilled under Lake Oahe, undertook an environmental impact assessment, and began looking at possible alternative routes. The encampment celebrated.

But in January, shortly after his inauguration, Donald Trump signed an executive order to move forward on the Dakota Access Pipeline as well as the controversial Keystone XL pipeline that threatens the Oglala Aquifer, one of the world's largest, underlying parts of seven Great Plains states. On 
February 7, construction resumed immediately. Most of the people had left the encampment by then although a few were removed and arrested by the militarized state police force that had been brutalizing the Water Keepers for months with beatings, tear gas, pepper spray, water-cannon, kennel-like holding pens, and aerial surveillance..$^{77}$ The intermeshed forces of oligarchic government and the energy industry won.

Still, Lyla June Johnston, a Navajo/Cheyenne activist and musician who joined the encampment at Standing Rock, voiced an optimism perhaps necessary, considering the immensity of the struggle: "We actually won this movement in so many profound ways... We have planted seeds all across the world and inspired and awakened people to see water in a new way, to see water as life. And we've also-for that matter, we have united things that were never united before." 58 She did not comment on the final irony that, with oil prices so low, the Bakken fields are now virtually deserted. North Dakota's oil boom has gone bust. Only a trickle of black crude will travel under the sacred lands and waters. ${ }^{59}$ Let's hope it all stays inside the pipeline.

\section{Conclusion}

In Native North America, as elsewhere, settler colonization has often resulted in a palimpsestic layering of colonial ideology over Indigenous life ways. Patriarchal misogyny is painted over Indigenous women-centered or egalitarian systems, and the settler stain spreads a thin but ugly veneer over Native culture. But in times of great cultural and environmental stress like our own, that original power, much like the old master hidden beneath the newer scribbling, shows through, and the time comes for women and girls once again to reassert the primacy of the inescapable connection among all entities. The stakes are high in their struggles:

57 Sandy Tolan, "Taxpayer-Funded Horror at Standing Rock," The Daily Beast (22 February 2017), http:// www.thedailybeast.com/articles/2017/02/22/taxpayer-funded-horror-at-standigrock.html.

58 “North Dakota: Police Raid Pipeline Resistance Camps, Arresting 33," Democracy Now (24 Feb 2017), https://www.democracynow.org/2017/2/24/headlines/north_dakota_police_raid_pipeline_resistance_ camps_arresting_33.

59 Ernest Scheyder, "In North Dakota's Oil Patch, a Humbling Comedown," Reuters Investigates (18 May 2016), http://www.reuters.com/investigates/special-report/usa-northdakota-bust/. 
In the final analysis, the survival of native America is fundamentally about the collective survival of all human beings. The question of who gets to determine the destiny of the land, and of the people who live on it-those with the money or those who pray on the land - is a question that is alive throughout society. ${ }^{60}$

As ecofeminist activists, the women and girls of Black Mesa and Standing Rock do the contemporary work of protecting the land and water and connecting people to each other and their cultural past and future. From that women's work, the whole world can benefit.

\section{Bibliography}

Acheman, Frank et al. "Sustainable Development for the Navajo Nation." Cambridge, Massachusetts: Synapse: Energy Economics, Inc, 2014. http://www.Synapse-energy.com. Accessed 5 March 2017.

Arasim, Emily and Osprey Orielle Lake. "15 Indigenous Women at the Frontlines of the Dakota Access Pipeline Resistance.” Women's Earth and Climate Action Network, 29 October 2016.

http://www.ecowatch.com/indigenous-women-dakota-access-pipeline-2069613663.html. Accessed 4 February 2017.

Biello, David “Are Pipelines Safer Than Railroads for Carrying Oil?" Scientific American, July 10, 2013. https://blogs.scientificamerican.com/observations/are-pipelines-saferthan-railroads-for-carrying-oil/ Accessed March 10, 2017.

"Black Day for The Diné." The Economist, 30 October 2000:17.

Black Mesa Water Coalition. "No Coal and Environmental Justice Program."

http://www.blackmesawatercoalition.org/no-coal-and-environmental-justice. Accessed 3 April 2017.

Boaz, Franz, ed. Keresan Texts, volume VIII, part 1, New York: Publications of the American Ethnological Society, 1928.

Brave Bull Allard, LaDonna. "Why the Founder of Standing Rock Sioux Camp Can't Forget the Whitestone Massacre." YES! Magazine. http://www.yesmagazine.org/peoplepower/why-the-founder-of-standing-rock-sioux-camp-cant-forget-the-whitestone-massacre-20160903. Accessed 10 February 2017.

Caitlin, Sislin. "The Navajo Nations Green Economy." Earth Island Journal, 25, 2 (Summer, 2010).

http://www.earthisland.org/journal/index.php/eij/article/womens_earth_alliance1/. Accessed 20 March 2017.

Clark, Roger. "Navajo Generating Station's Closing Curtain?" Grand Canyon Trust. http:// www.grandcanyontrust.org/blob/navajo-generating-station-closing. Accessed 15 March 2017.

Deloria, Vine, Jr. Custer Died for Your Sins. Avon Books, 1969; Reprinted with a new preface, Norman: University of Oklahoma Press, 1988. 
Eide, Elizabeth. "Strategic Essentialism and Ethnification." Nordicom Review 31, no. 2 (2010): 63-78. http://www.nordicom.gu.se/en/tidskrifter/nordicom-review-22010/strategic-essentialism-and-ethnification-hand-glove. Accessed 15 March 2017.

Elbein, Saul."These Are the Defiant 'Water Protectors' of Standing Rock." National Geographic. http://news.nationalgeographic.com/2017/01/tribes-standing-rock-dakota-access-pipeline-advancement/. Accessed 15 December 2016.

Erdoes, Richard and Alfonso Ortiz. American Indian Myths and Legends. New York: Pantheon, 1986.

Folger, Tim. “A Thirsty Nation.” On Earth Magazine, Fall 2004.

http://wwwnrdc.org/onearth/o4fall/blackmesa1 .asp. Accessed 10 March 2017.

"From Hero to Zero: Peabody Energy Corp." The Economist. Case_resolution_fictconsulting.pdf. Accessed 10 November 2017.

Giacomini, Terran. "Ecofeminism and System Change: Women on the Frontlines of the Struggle Against Fossil Capitalism and for the Solar Commons." Canadian Woman Studies 31, 1-2 (2014): 95-107.

Goeman, Mishuana R., and Jennifer Nez Denetdale. "Native Feminisms: Legacies, Interventions, and Indigenous Sovereignties.” Wicazo Sa Review 24, 2 (Fall 2009): 169-187.

Green, Joyce. "Taking Account of Aboriginal Feminism." in Making Space for Indigenous Feminism, Edited by Joyce Green. Winnipeg: Fernwood Publishing, 2007: 20-32.

Grinde, Donald A. and Bruce E. Johansen. Ecocide of Native America: Environmental Destruction on Indian Lands and Peoples. Santa Fe: Clear Light Publishers, 1995.

Gunn Allen, Paula. Grandmother of Light: A Medicine Woman's Sourcebook. Boston: Beacon Press, 1991.

. The Sacred Hoop: Recovering the Feminine in American Indian Tradition. Boston: Beacon Press, 1986.

John, Elvin. "United Nations to Investigate Navajo claims.” Insight. 2 March 1998, 14, 8.

LaDuke, Winona. All Our Relations. New York: South End Press, 1999.

. Recovering the Sacred: The Power of Naming and Claiming. New York: South End Press, 1999. Reprint Chicago: Haymarket Books, 2005.

Lajimodiere, Denise. "Ogimah Ikwe: Native Women and Their Path to Leadership." Wicazo Sa Review, 26, 2 (Fall 2011): 57-82.

Leonard, Scott, and Michael McClure. Myth and Knowing. New York: McGraw Hill, 2004.

"Light, Sweet Compromise." The Economist.

http://www.Economist.com/news/finance-economics21684531-light-sweet-compromise. Accessed 20 March 2017.

Masayesva, Vernon. "Black Mesa Trusts Applauds Decision to Shutter Navajo Generating Station.” Black Mesa Trust. http://www.blackmesatrust.org/. Accessed 15 March 2017.

Mooney, Chris and Steven Mufson. "How coal titan Peabody, the world's largest, fell into bankruptcy." The Washington Post, 3 April 2016. https://www.washingtonpost. com/news/energy-environment/wp/2016/04/13/coal-titan-peabody-energy-files-forbankruptcy/?utm_term=.46fed1df5144. Accessed 10 September 2017.

Murphy, Lucy Eldersveld. "Native American Women's History: Tribes, Leadership, and Colonialism." Journal of Women's History 17, 4: 124-133. Project Muse. Accessed 2 March 2017.

Needham, Andrew. Power Lines: Phoenix and the Making of the Modern Southwest. Princeton: Princeton University Press, 2014.

Nhanenge, Jytte. Ecofeminism: Towards Integrating the Concerns of Women, Poor People, and Nature into Development. New York: University Press of America, 2011.

Nies, Judith. Unreal City: Las Vegas, Black Mesa, and the Fate of the West. New York: Na- 
tion Books, 2014.

"North Dakota: Police Raid Pipeline Resistance Camps, Arresting 33." Democracy Now, 24 Feb 2017. https://www.democracynow.org/2017/2/24/headlines/north_dakota_police_raid_pipeline_resistance_camps_arresting_33. Accessed 20 March 2017.

Ortiz, Simon. From Sand Creek. Thunder Mouth Press, 1981. Reprinted with a new preface, Tucson: University of Arizona Press, 1999.

Peter, Enei Begaye. "Navajo Restorative Economy Program.” Black Mesa Water Coalition. http://www.blackmesawatercoalition.org/navajo-restorative-economy. Accessed 3 April 2017.

Purdue, Theda, ed. Sifters: Native American Women's Lives. Oxford: Oxford University Press, 2001.

Ruoff, A.Lavonne. "Ritual and Renewal: Keres Traditions in Leslie Silko's 'Yellow Woman'." "Yellow Woman": Leslie Marmon Silko. Edited by Melody Graulich. New Brunswick: Rutgers, 1993: 69-81.

Scheyder, Ernest. "In North Dakota's Oil Patch, a Humbling Comedown.” Reuters Investigates, 18 May 2016. http://www.reuters.com/investigates/special-report/usa-northdakota-bust/. Accessed 3 March 2017.

Smith, Andrea. "Native American Feminism, Sovereignty, and Social Change." Feminist Studies 31, 1 (Spring, 2005): 116-132.

"Dismantling the Mater's Tools with the Master's House: Native Feminist Liberation Theologies." Journal of Feminist Studies in Religion 22, 2 (2006): 85-97.

Smith, Patricia, and Paula Gunn Allen. "Earthly Relations, Carnal Knowledge: Southwestern American Indian Women Writers. "Yellow Woman": Leslie Marmon Silko. Edited by Melody Graulich. New Brunswick: Rutgers, 1993: 115-150.

Sprague, Donovan Arleigh. Images of America: Standing Rock Sioux. Charleston, South Carolina: Arcadia Press, 2004.

St. Denis, Verna. "Feminism Is for Everybody: Aboriginal Women, Feminism and Diversity." Making Space for Indigenous Feminism, Edited by Joyce Green. Winnipeg: Fernwood Publishing, 2007: 33-52.

Tolan, Sandy. "Taxpayer-Funded Horror at Standing Rock." The Daily Beast, 22 February 2017. http://www.thedailybeast.com/articles/2017/02/22/taxpayer-funded-horror-atstandigrock.html. Accessed 20 March 2017.

Tompkins, Rose. Unpublished Interview. Columbia, Missouri: 19 April 2007.

Whyte, Kyle Powys. "The Dakota Access Pipeline, Environmental Injustice, and U.S. Colonialism.” In press at Red Ink: An International Journal of Indigenous Literature, Arts, and Humanities, January/February, 2017.

https://papers.ssrn.com/sol3/papers.cfm?abstract_id=2925513. Accessed 24 February 2017. 